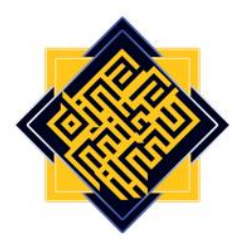

\title{
Instructional Leadership Style at MAN 1 Samarinda
}

\author{
Suratman \\ State Islamic Institute of Samarinda, Indonesia \\ e-mail: suratman.pambudi@gmail.com
}

\begin{abstract}
The aim of this research is to describe instructional leadership as one of the leadership styles in the context of Madrasah Aliyah teaching and learning, typically at MAN 1 Samarinda, East Kalimantan. In-depth interviews with the school principal and representative teachers from all levels were conducted in order to dig information regarding the research focus. Additionally, document analysis is also used to support the findings gained from in-depth interviews specifically related to the document of school vision and mission and supervision of teachers' performance. As a result, three dimensions of instructional leadership exist in the implementation of instructional leadership at MAN 1 Samarinda, i.e. the school principal supports in terms of the implementation of school vision and mission, management of school program, and positive teaching and learning climate. Even though this research gains positive results regarding with the implementation of instructional leadership, some previous studies in this research reveal that there are quite many formal schools who are still lack of knowledge concerning with leadership styles especially instructional leadership. Therefore, the pedagogical implication of this research findings drives the involvement of the government in supporting school principal in any formal institution, especially in enriching their knowledge in implementing appropriate leadership styles. Research novelty and pedagogical implications are discussed further in this research.
\end{abstract}

Keywords: instructional leadership, leadership implementation, leadership style 


\section{Suratman}

\section{A. Introduction}

The duty of school principals in the $21^{\text {st }}$ century is a demand of education, especially in the era of digitalization which is full of global competition. For this reason, the duty of a leader at school is to ensure school members can implement vision and mission, develop adaptive curriculum, monitor the process of learning activities through academic supervision, monitor students' progress, and create a conducive learning atmosphere (Esti, 2011). Meanwhile, Davis \& Newstrom (1995) said that the principal's job is to provide facilities to teachers for professional development, improve student achievement through innovation and curriculum management, bridge and facilitate the learning process to become an effective organization for all students.

Based on Peraturan Menteri Pendidikan dan Kebudayaan Republik Indonesia No. 6 (2018), article 15 paragraph 1, the duties of the principal are entirely managerial and supervise educators and educational employee. It means that the role and function of the principal should be the focus on the development of school since there is no demand for the principal to teach at school. Therefore, school principals have more time to run managerial and learning coaching. Additionally, school principals also should ready for innovation and curriculum development that can improve students' achievement through learning supervision.

Recently, the principal in carrying out his main duties and functions is still dominant in managerial or administrative functions. Stronge (1988) stated that the allocation made by the principal is only ten percent for learning activities due to a lack of time and instructional leadership training. The role of the principal as a leader of learning is to bring all school members to believe and want to change for lifelong learning, have a commitment to student services, and the learning process is directed at quality with continuous improvement.

In a study conducted by Sari \& Sukoco (2015), the result showed that the implementation of academic in Bengkulu by the principal could increase the effectiveness of coaching by the principal, specifically on supervision preparation, implementation, and follow up. However, those three components still have problems with long and complicated bureaucratic conditions, as well as less professional human resources. What barriers do not distract the duties of principal and keep increasing competence through School Principal Working Group and Educator Working Group as a place to develop skills and to improve the quality in education specifically in Bengkulu. In line with Sari \& Sukoco (2015), Wahono \& Jabar (2016) found that the effectiveness of academic supervision that has been carried out by principals and efforts to improve educators' competencies are considered very effective. The stage of implementing supervision including preparation, implementation, assessment, and follow-up. It aims to improve the quality of education services.

Specifically, the principal as a leader will determine the effectiveness of education quality assurance. It is showed from a study conducted by Sustiwi \& Muhyadi (2016) where the quality assurance leadership obtained effective results from all aspects i.e. planning, process implementation, evaluation, and monitoring. However, some school principals in Indonesia are still burdened with managerial tasks that make them cannot do their job as they should be. Therefore, adequate knowledge regarding with leadership styles is vital at 
any school since its existence determines the success of the teaching and learning process as well as the quality of the school as a whole (Nurdianti \& Nurdin, 2020).

Moreover, leadership style is considered to be very important in any institution, including formal schools. In this case, the most appropriate leadership to be implemented in schools is instructional leadership. This pattern is the main element for schools in educating students and all stakeholders to be involved in achieving decent learning outcomes in the form of attitude, cognitive, and psychomotor. This principle is to prepare students to become successful adults and be able to overcome all obstacles (Tanama et al., 2016). Many studies have conducted similar study especially regarding with leadership of school principal in implementing school management i.e. Abdulbar et al. (2015), Ansar et al. (2019), Bukhari (2012), Bush (2015), Darmawati (2016), Hastuti et al. (2020), Magdalena (2012), Muttaqin (2020), Mahmud (2012), Nsubuga (2008), and Nadhirin (2017). Specifically, to one of the leadership types of the school principal, instructional leadership is also one of the famous researches focuses in school management. Some researchers also choose instructional leadership as their research focus i.e. Esa et al. (2018), Basañes (2020), Hatta (2014), Khoiri (2019), Petrovic \& Vracar (2019), Puspitaningtyas et al. (2019), Ruebling et al. (2004), and Tanama et al. (2016).

However, even though there are quite many previous studies that found positive facts regarding with instructional leadership implemented by the school principal, there are some schools in a certain level of education that still have poor knowledge related to instructional leadership (Basañes, 2020). Thus, different findings by the previous studies make the researcher eager to investigate the similar focus, which is instructional leadership in different sites i.e. Madrasah Aliyah Negeri 1 Samarinda, with a high expectation that the research findings will drive to significant novelty.

\section{B. Literature Review}

\section{The Concept of Instructional Leadership}

Instructional leadership focuses on the act of school principals who pay attention to the teaching and learning process that is tailored to the development of students (Southworth, 2002). It is also a real action in improving students' learning achievement through creating a conducive environment and generating a sense of satisfaction for teachers (Akkary \& Greenfield, 1998). Additionally, instructional leadership is a behavior carried out by the principal in describing his performance which has results that give spirit and warm feeling to teachers (Khoiri, 2019). A big effort should be made by a school principal as an educator leader in order to take better teaching actions to improve students' achievement in learning (Daresh \& Playco, 1995).

Furthermore, the main goal of instructional leadership is to shape a leader's behavior in schools that encourage learning to be more as expected. Sergiovanni's instructional leadership aspects include technical aspects, the person who acts as a leader, implicit and cultural aspect (Khoiri, 2019). These five aspects are the basic component that must be developed by a leader by taking into account all the challenges that possible to face in the future. In principle, according to the above experts, leading a teacher is actually a teaching 


\section{Suratman}

and learning activity covering aspects of curriculum, teaching process, assessment, improvement of teacher profession, maximum service in the teaching process. Therefore, instructional leadership requires an action that adapts to the condition and potential that exist at school, taking into account the strengths, weaknesses, threats, and opportunities to increase the effectiveness of all services at school.

In order to reveal an effective instructional leadership, there are five characterized aspects that must be done by a principal i.e. (a) create, socialize, apply vision and mission in everyday activities at school, (b) implement a leadership pattern that involves all stakeholders in decision making, (c) provide maximum support for learning process both inside and outside the classroom, (d) guide teachers from planning, implementation, evaluation so ha a reflection of learning in schools is obtained, and (e) act as a companion in managing problems of the teaching and learning process (Patterson \& Purkey, 1993). Moreover, there are three dimensions of instructional leadership based on the theory from Hallinger \& Murphy (1985), which include schools' vision and mission, school program management, and positive teaching and learning atmosphere.

\section{Important Elements in Instructional Leadership and its Contributions to the Successfulness of School Management}

The principal is a figure who plays a very important role and has a direct impact on his leadership to have a dominant influence on students' achievement after learning. This condition can be achieved by inviting all school users to focus more on their work to achieve the vision and mission of the school. The implementation of instructional leadership can be gained by the support of all elements at school. Additionally, to achieve a qualified education system, the school principal should make teamwork to create opportunities for learning innovation (Tanama et al., 2016).

Instructional leadership support is to facilitate the achievement of vision and mission determined by the school management. According to Wahyudi et al. (2020), learning management in instructional leadership is carried out by implementing learning supervision to determine the development of students by coordinating the community demands and expectations. The principal develops the school to create a conducive atmosphere, teacher professional development, and provide a reward for high achieving teachers and students. Thus, it can be said that instructional leadership is very important since its existence influences school achievement.

Important points in carrying out tasks with accountability as school principals in order to improve the quality of education including the role of the principal as a serving leader, develop participatory leadership styles and avoid authoritarian styles in a flexible manner, working professionalism, and maintaining the goals to be achieved by the school (Nsubuga, 2008). In instructional leadership, the assessment of the principal begins with self-reflection in order to achieve a strategic plan that has been set. The key indicator is that the principal communicates multidirectional communication with staff and teachers by relying on the standard of support learning, multiple sources of reflection and ensure all activities inside or outside of the classroom remain in the standard of the learning process. 
Furthermore, school atmosphere influences the success of students' learning through five components, including creative and collaborative learning community, belief in achieving goals, increasing school achievement through problem-solving, confidence building, and priority of teaching and learning (Peariso, 2011). Related to the aspect of school atmosphere, the behavior of school principal in implementing instructional leadership should cover some aspects, including creating a safe and comfortable school, familiarize and assess the behavior of school members in a sustainable manner, deepen the professionalism of individual teachers, sorting out appropriate load that can support school activities, bridging information with staff and teachers to achieve decent learning outcomes. Thus, the instructional leadership behavior can obtain effective results. In order to create an effective instructional leadership, there are six main principles that a school principal should notice according to Southworth (2002), including (a) monitoring teacher performance, (b) conducting performance evaluation, (c) assistance and supervision, (d) building sustainable professional development, (e) forming teamwork, and ( $f$ ) coordinating the learning process to be effective.

The role of instructional leadership is very dominant in enhancing the working atmosphere among teachers as well as building the working discipline of teachers. The success of the school principal in this context is how to build a learning society by becoming a motivator for teachers in a responsible manner (Purwoko, 2018). Additionally, the contribution of instructional leadership a school is shaping the school culture, a conducive environment for implementing a learning community in order to increase the effectiveness of the learning model (Syarli et al., 2020). Alike with Syarli et al. (2020), Kusumaningrum et al. (2020) explained that instructional leadership increases teachers' teaching competencies and optimize character building and culture shaping at school. In short, instructional leadership influences the quality of the teaching and learning process, including teachers' competencies, classroom management, etc.

\section{Research Methodology}

This research is qualitative research where the natural phenomenon was investigated and described naturally in this research (Gay et al., 2012; Cresswell, 2003). In this case, this research focused on the description of how instructional leadership strategy is performed by the school principal in one of Madrasah Aliyah in Samarinda i.e. Madrasah Aliyah Negeri 1, or known as MAN 1. Particularly, instructional leadership analyzed in this research focuses on three dimensions of instructional leadership proposed by Hallinger \& Murphy (1985). Moreover, since this research was conducted in the pandemic situation, so it is not possible for the researcher to have a direct observation of the school. Therefore, the main data in this research was gained from an in-depth online interview (Cresswell, 2005; Taylor et al., 2016) with the school principal in order to obtain information regarding with instructional leadership that the school principal implement at school. Additionally, to support the data obtained from the school principal, the researcher also conducted an in-depth interview with one teacher from the first grade, one teacher from the second grade, and one teacher from the third grade. It is aimed to confirm the data got from the school principal. Other 


\section{Suratman}

than that, document analysis (Yin, 2011; Denzin \& Lincoln, 2005) was also managed to support the findings in this research specifically regarding with vision and mission and teachers' performance supervision documents. In terms of analyzing the data, the researcher used Sonix application to have interview transcription. In this case, interview transcription eases the researcher to analyze the data by following three steps of flow chart analysis proposed by Miles et al. (2014) i.e. data condensation, data display, and verification/ conclusion.

\section{Findings and Discussion}

As the result of this study, the below table describes how instructional leadership dimensions appear and implement at MAN 1 Samarinda.

Table: The instructional leadership dimensions at MAN 1 Samarinda

\begin{tabular}{|c|c|c|}
\hline $\begin{array}{l}\text { Instructional } \\
\text { leadership } \\
\text { dimensions }\end{array}$ & $\begin{array}{l}\text { Application of instructional leadership done by } \\
\text { the principal of MAN } 1 \text { Samarinda }\end{array}$ & $\begin{array}{l}\text { Effect of instructional } \\
\text { leadership implemented } \\
\text { by the school principal of } \\
\text { MAN } 1 \text { Samarinda }\end{array}$ \\
\hline \multirow{2}{*}{$\begin{array}{l}\text { School vision and } \\
\text { mission application }\end{array}$} & $\begin{array}{l}\text { Review of school vision and mission by involving all } \\
\text { important elements at school }\end{array}$ & \multirow{10}{*}{$\begin{array}{l}\text { The school gained many } \\
\text { prestigious awards i.e. } \\
\text { Adiwiyata or awards for } \\
\text { clean school, best library, } \\
\text { academic and non- } \\
\text { academic achievements } \\
\text { gained by both teachers } \\
\text { and students. }\end{array}$} \\
\hline & $\begin{array}{l}\text { Supervise the lesson plan of teachers before } \\
\text { teaching and ensure whether the content has } \\
\text { already met the vision of the school }\end{array}$ & \\
\hline \multirow{4}{*}{$\begin{array}{l}\text { School program } \\
\text { management }\end{array}$} & $\begin{array}{l}\text { Support the facilities which can ease teachers in } \\
\text { conducting teaching and learning process }\end{array}$ & \\
\hline & Involve teachers in decision-making & \\
\hline & $\begin{array}{l}\text { Maximize the role of parents' committee and } \\
\text { government }\end{array}$ & \\
\hline & $\begin{array}{l}\text { Conduct routine supervision for teachers' } \\
\text { performance }\end{array}$ & \\
\hline \multirow{4}{*}{$\begin{array}{l}\text { Positive teaching } \\
\text { and learning } \\
\text { atmosphere }\end{array}$} & $\begin{array}{l}\text { Give reward to both teachers and students' } \\
\text { achievement }\end{array}$ & \\
\hline & Maintain teacher's motivation in teaching & \\
\hline & Support training for teachers' development & \\
\hline & $\begin{array}{l}\text { Maximize the participation of teachers on MGMP as } \\
\text { a forum for teachers }\end{array}$ & \\
\hline
\end{tabular}

From the interview with the school principal, the researcher found some important facts regarding with the instructional leadership implemented at MAN 1 Samarinda. The first instructional leadership strategy is the aspect of the decision-making process. In this case, the school principal always makes a small team representing all components; then, the draft is discussed in regular meetings to make decisions in order to achieve the target set. This finding is confirmed by the teachers interviewed by the researcher, where all teachers at school always get involved in every meeting in order to have decision-making together.

Secondly, in terms of human resource, the school principal provides supports to the development of human resource at school by optimizing MGMP or known as a forum for teachers to develop teaching professionalism in Samarinda, provides routine training for 
teachers inside and outside the school, as well as giving reward to teachers and students who gain decent achievement. In this case, teachers interviewed by the researcher said that the school principal always gives support for teachers to be active in MGMP forum, provides wide opportunities for teachers for any teacher training development, as well as appreciates teachers with their achievement. This research finding is confirmed by the research findings from Petrovic \& Vracar (2019) where a decent instructional leadership implemented by a school principal is indicated from the behavior of the principal to support and motivate teachers in conducting teaching activities at school.

Thirdly, in terms of facilities, the school principal increases the completeness of the laboratory, funding support for teaching and learning media. This part of instructional leadership, of course giving a positive impact on students' learning activeness and teachers' teaching creativity (Effendi, 2016; Ginting, 2017; Suprianto et al., 2016). This fact is in line with the information given by the teachers interviewed by the researcher where the facilities provided by school management are enough and well-equipped so that teachers are able to run the teaching and learning process smoothly. Additionally, the school principal also maximizes the participation from parents' committees and the government to support funding of school facilities. This fact indicates that the school principal is a leader who always maintains the relationship with parents and government in order to enlarge the school development.

The above findings are appropriate with the theory from Southworth (2002) where supports given the teaching and learning, rewards allocation for teachers and students, as well as supervision to the teachers' performance become the aspects included in effective instructional leadership implementation. In other words, it can be said that the leadership style of the school principal has a positive correlation with the teachers' performance (Paizal et al., 2019).

There were two types of document which investigated in this research i.e. vision and mission and teachers' performance supervision. In terms of the vision and mission of MAN 1 , as a leader, the school principal conducted a review of vision and mission after five years of vision and mission implementation. In this case, participants involved in this agenda were the principal and all teachers, head of administration and staff, representative of parents' committee, school supervisor, representative of East Kalimantan Environment office. From the document of minute, the meeting found that the result of the vision and mission review was to revise the vision to become more on global competitiveness and environmental preservation. Meanwhile, the mission was also revised become implementing contextualbased learning, improving student achievement, implementing practices with business and industrial world, and increasing the achievement of students in the field of scientific learning from National to International levels, as well as mentoring the teaching profession with learning supervision with school teams and supervisors of the Ministry of Religious Affairs.

Related to the above findings, the attention of the school principal concerning with vision and mission gives opportunities for the school to utilize internal strength which can have a direct impact on teachers and students' achievement. These findings are supported by research from Mukhibat (2020) where in his research showed that school vision and 


\section{Suratman}

mission building becomes one of the strategies in instructional leadership that can build local and global values embedded in teachers' and students' characteristics. Additionally, in a research's findings of Tanama et al. (2016), the vision and mission of a school can be wellachieved from the maximum efforts in implementing instructional leadership.

Other than the document of vision and mission, the researcher also found the document of supervision from the school principal to teachers' performance. In this case, the terms supervised by the school principal include several aspects i.e. teaching preparation, teaching stages, learning evaluation, teaching media, and appropriateness to the teaching implemented by teachers to the curriculum integration with living environmental based. This result is supported by Werdayanti (2008), Wardhana (2016), Hambali (2017), and Nurdin \& Usman (2013) where they found that supervision from principal can increase the teachers' competencies as well as encourage teachers' commitment in increasing teaching professionalism. Additionally, alike with above previous studies, Latief \& Masruroh (2016) also pointed out that supervision can improve teacher performance characterized by a more settle teaching plan, teaching material mastery, variation in teaching methods, improve discipline character, and activate active learning method.

Furthermore, additional findings were also found by the researcher in terms of document analysis. In this case, instructional leadership of the school principal was showed from the achievement of the school sanitation, completeness of school library, outstanding teachers and students both in academic and non-academic fields on local, national, and international levels. This additional finding on document analysis found by the researcher indicates that effective instructional leadership will have a direct impact on the students' learning outcomes (Bush, 2015) as well as on teachers' performance and achievement (Petrovic \& Vracar, 2019). The novelty of the research findings drives to one highlighted point, which is significantly different from previous studies. It is a decision-making process that becomes the important point to build a new research gap that did not exist in the previous studies.

\section{E. Conclusion}

From the findings explored above, it can be concluded that all three dimensions of instructional leadership exist in the instructional leadership style implemented by the school principal of MAN 1 Samarinda. Specifically, the school vision and mission can be achieved well where it can be seen from the management of school programs and positive teaching and learning climate. All of the aspects of instructional leadership dimensions produce a decent learning outcome where both teachers and students have achieved many rewards for academic and non-academic achievements. Additionally, all of the information given by the school principal regarding with instructional leadership implemented at school is confirmed by three teachers interviewed in this research. In order to obtain maximum learning outcomes, the school principal gives total attention in supporting teachers in terms of facilities such as the media needed by the teachers to teach as well as maintaining teachers' motivation in teaching and giving rewards towards teachers' achievement. In 
addition, to keep the quality of teaching and learning, the school principal conducts routine supervision to teachers' teaching performance. From the positive results in this research, the pedagogical implication reveals in this research is the involvement of the government in enriching information and knowledge regarding with leadership styles e.g. instructional leadership styles.

\section{BIBLIOGRAPHY}

Abdulbar, A., Asmara, U. H., \& Sindju, H. B. (2015). Kepemimpinan Kepala Madrasah dalam Meningkatkan Profesional Guru pada MAN Ngabang Kabupaten. Jurnal Pendidikan Dan Pembelajaran Khatulistiwa, 4(6).

Akkary, R., \& Greenfield, W. (1998). Leadership and Work Context of Public and Private Secondary Schools in the Republic of Lebanon. The Annual Meeting of the American Educational Research.

Andriani, D. E. (2011). Kepemimpinan Kepala Sekolah Abad 21. Retrieved from: http://staffnew.uny.ac.id/upload/132297327/pengabdian/Kepemimpinan+Kepala+Sek olah+Abad+21.pdf

Ansar, A., Marzuki, K., \& Tolla, I. (2019). Transformation Leadership of Headmaster to Improving Teacher Learning Performance in SMP Islam Al-Azhar Makassar City. Advances in Social Science, Education and Humanities Research, 303, 99-102. https://doi.org/10.2991/icpeopleunnes-18.2019.20

Basañes, R. A. (2020). Instructional Leadership Capacity of Elementary School Administrators. GATR Global Journal of Business Social Sciences Review, 8(2), 113-123. https://doi.org/10.356og/gjbssr.2020.8.2(5)

Bukhari, A. (2012). Kepemimpinan Transformasional Pendidikan Berbasis Total Quality Management (TQM). DINAMIKA ILMU, 12(2).

Bush, T. (2015). Understanding Instructional Leadership. Educational Management Administration and Leadership, 43(4), 487-489. https://doi.org/10.1177/1741143215577035

Cresswell, J. (2003). Research Design, Qualitative, Quantitative, and Mixed Method Approach (2nd ed.). Sage Publications.

Cresswell, J. (2005). Research Design: Qualitative and Quantitative Approaches. Longman.

Daresh, J. W., \& Playco, P. (1995). Supervision as a Proactive Process. Waveland Press, Inc.

Darmawati, D. (2016). Model Kepemimpinan Kepala MIN 1 dan MIN 2 Sekota Samarinda. Syamil, 4(1), 1-21.

Davis, K., \& Newstrom, N. (1995). Perilaku dalam Organisasi. Erlangga.

Denzin, N. K., \& Lincoln, Y. S. (2005). Handbook of Qualitative Research. SAGE Publication Inc.

Effendi, M. (2016). Integrasi Pembelajaran Active Learning dan Internet-Based Learning dalam Meningkatkan Keaktifan dan Kreativitas Belajar. Nadwa, 7(2), 283-309. https://doi.org/https://doi.org/10.2158o/nw.2013.7.2.563 


\section{Suratman}

Esa, N. bt. A., Muda, M. S. B., Mansor, N. R. B., \& Ibrahim, M. Y. B. (2018). Literature Review on Instructional Leadership Practice among Principals in Managing Changes. International Journal of Academic Research in Business and Social Sciences, 7(12), 18-24. https://doi.org/10.6007/ijarbss/v7-i12/3588

Gay, L. R., Mills, G. E., \& Airasian, P. . (2012). Educational Research: Competencies for analysis and applications. Pearson.

Ginting, S. A. (2017). A Facilitating Effective Teaching through Learning Based on Learning Styles and Ways of Thinking. DINAMIKA ILMU, $17(2)$. https://doi.org/https://doi.org/10.21093/di.v17i2.850

Hallinger, P., \& Murphy, J. (1985). Assessing the Instructional Management Behavior of Principals. Elementary School Journal, 86.

Hambali, M. (2017). Kepemimpinan Berbasis Core Values Sekolah Unggulan di Malang. MANAGERIA: Jurnal Manajemen Pendidikan Islam, 2(1). https://doi.org/https://doi.org/10.14421/manageria.2017.21-02

Hastuti, T., Kristiawan, M., \& Mulyadi. (2020). The Principal's Leadership in Improving the Quality of Education. International Journal of Progressive Sciences and Technologies, 22(1), 314-320. http://www.ijpsat.es/index.php/ijpsat/article/view/2067/1184

Hatta, M. (2014). Instructional Leadership: an Islamic Perspective. Jurnal Pencerahan, 8(1), 67-72. https://doi.org/10.13170/jp.8.1.2044

Khoiri, N. (2019). Kepemimpinan Pembelajaran Kepala Madrasah: Kontribusi Motivasi Kerja, Iklim Sekolah dan Kepuasan Kerja Pada Madrasah Aliyah. Southeast Asian Publishing.

Kusumaningrum, D. E., Sumarsono, R. B., \& Gunawan, I. (2020). Pengaruh Kepemimpinan Pembelajaran, Kepemimpinan Perubahan, Kepemimpinan Spiritual, Budaya Sekolah, Dan Etika Profesi Terhadap Kinerja Mengajar Guru. JMSP (Jurnal Manajemen Dan Supervisi Pendidikan), 4(3).

Latief, J., \& Masruroh, N. A. (2016). Kepala Madrasah Sebagai Supervisor Akademik Untuk Meningkatkan Kinerja Guru MTs N Donomulyo Kulonprogo. MANAGERIA: Jurnal Manajemen Pendidikan Islam, $1(2)$. https://doi.org/https://doi.org/10.14421/manageria.2016.12-06

Magdalena, M. (2012). Revitalisasi Madrasah Diniyah Awaliyah melalui Pendekatan Manajemen Berbasis Madrasah. DINAMIKA ILMU, 12(2). http://iainsamarinda.ac.id/ojs/index.php/dinamika_ilmu/article/view/63

Mahmud, M. E. (2012). Motif Penyelenggaraan Pendidikan Islam dan Implikasinya pada Pola Manajemen dan Kepemimpinan. DINAMIKA ILMU, 12(2).

Miles, M. B., Huberman, A. M., \& Saldana, J. (2014). Qualitative Data Analysis: A Methods Sourcebooks (3rd ed.). SAGE Publications, Inc.

Mukhibat, M. (2020). Virtual Pesantren Management in Indonesia: In Knowing Locality, Nationality, and Globality. DINAMIKA ILMU, 2O(1). https://doi.org/https://doi.org/10.21093/di.v2oi1.1950

Muttaqin, I. (2020). Types and Characteristics of Kyai Leadership Within Pesantren. Dinamika Ilmu, 20(1), 165-174. https://doi.org/10.21093/di.v20i1.2446

Nadhirin, N. (2017). The Leadership of the Head of Madrasah in Establishing Communication 
With Stakeholder. ADDIN, 11(2), 485. https://doi.org/10.21043/addin.v11i2.3344

Nsubuga, Y. K. (2008). Analysis of Leadership Styles and School Performance. In Unpublised

Thhesis (Issue December). Nelson Mandela Metropolitan University.

Nurdianti, L., \& Nurdin, D. (2020). Instructional Leadership in Improving the Quality of Elementary School Education in Bandung. Advances in Social Science, Education and Humanities Research, 400(Icream 2019), 348-351. https://doi.org/10.2991/assehr.k.200130.200

Nurdin, M., \& Usman, H. (2013). Kepemimpinan Kepala Sekolah Dasar Negeri 1 Taliwan Kabupaten Sumbawa Barat. Jurnal Akuntabilitas Manajemen Pendidikan, 1(2). https://doi.org/https://doi.org/10.21831/amp.v1i2.2395

Paizal, I., Siraj, A., \& Mania, S. (2019). Hubungan Gaya Kepemimpinan Kepala Madrasah dengan Kinerja Guru di Madrasah Aliyah Pondok Pesantren Al-Ikhlas Ujung Bone. Jurnal Pendidikan Agama Islam Al-Thariqah, 4(1), 21-37. https://doi.org/10.25299/althariqah.2019.vol4(1).3003

Patterson, C. H., \& Purkey, W. W. (1993). The Preparation of Humanistic Teachers for Next Century Schools. The Journal of Humanistic Education and Development, 30, 147-155.

Peariso, J. F. (2011). A Study of Principals' Instructional Leadership Behaviors and Beliefs of Good Pedagogical Practice among Effective California High Schools Serving Socioeconomically Disadvantaged and ENglish Learners. Liberty University.

Peraturan Menteri Pendidikan dan Kebudayaan Republik Indonesia No. 6. (2018). Penugasa Guru Sebagai Kepala Sekolah. Kementerian Pendidikan dan Kebudayaan Republik Indonesia.

Petrovic, D. S., \& Vracar, S. (2019). Understanding and Defining Instructional Leadership: School Principals' Perspective, in Psychological Applications and Trends, 114-118. https://doi.org/10.36315/2019inpacto28

Purwoko, S. (2018). Pengaruh Kepemimpinan Kepala Sekolah, Komitmen Guru, Disiplin Kerja Guru, dan Budaya Sekolah Terhadap Kinerja Guru SMK. Jurnal Akuntabilitas Manajemen Pendidikan, 6(2). https://doi.org/https://doi.org/10.21831/amp.v6i2.8467

Puspitaningtyas, I., Satria, R., Maisyaroh, \& Sumarsono, R. B. (2019). Implementasi Kepemimpinan Pembelajaran Di Satuan Pendidikan. PROSIDING SEMINAR NASIONAL Revitalisasi Manajemen Pendidikan Anak Usia Dini (PAUD) di Era Revolusi Industri 4.0

Ruebling, C. E., Stow, S. B., Kayona, F. A., \& Clarke, N. A. (2004). Instructional leadership: An essential ingredient for improving student learning. Educational Forum, 68(3), 243253. https://doi.org/10.1080/00131720408984636

Sari, A. L., \& Sukoco, S. (2015). Keefektifan Supervisi Akademik Oleh Kepala Sekolah Dasar Negeri Se-Kecamatan Talang Empat Bengkulu Tengah. Jurnal Akuntabilitas Manajemen Pendidikan, 3(1), 1-12. https://doi.org/https://doi.org/10.21831/amp.v3i1.6266

Southworth, G. (2002). Instructional Leadership in Schools: Reflections and Empirical Evidence. School Leadership \& Management, 22, 73-91. https://doi.org/http://dx.doi.org/10.1080/13632430220143042

Stronge, J. H. (1988). The Elementary School Principalship: A Position in Transition? 


\section{Suratman}

Principal, 67(5).

Suprianto, S., Kholida, S. I., \& Andi, H. J. (2016). Pengaruh Pendekatan Contextual Teaching and Learning (CTL) Berbantuan Media Powerpoint terhadap Peningkatan Hasil Belajar IPA Fisika. Jurnal Penelitian dan Pembelajaran IPA, 2(2). https://doi.org/https://doi.org/10.30870/jppi.v2i2.427

Sustiwi, R., \& Muhyadi, M. (2016). Keefektifan Penjaminan Mutu Standar Proses di SDN Kaliurang 2 Kecamatan Pakem Kabupaten Sleman. Jurnal Akuntabilitas Manajemen Pendidikan, 4(1). https://doi.org/https://doi.org/10.21831/amp.v4i1.8193

Syarli, S., Arif, Y., Fatmadona, R., \& Arini, L. (2020). Studi Komparatif Efektifitas Model Pembelajaran Klinik One Minute Preceptor (OMP) dan Snapps Terhadap Pencapaian Kompetensi Mata Kuliah Kepemimpinan dan Manajemen Keperawatan Mahasiswa Profesi Ners Fkep Unand. Jurnal Keperawatan Muhammadiyah, 5(1).

Tanama, Y. J., Bafadal, I., \& Degeng, I. N. (2016). Pentingnya Kepemimpinan Pembelajaran di Sekolah. Prosiding Seminar Nasional Mahasiswa Kerjasama Direktorat Jenderal Guru Dan Tenaga Kependidikan Kemendikbud, 1-7.

Taylor, S. J., Bogdan, R., \& DeVault, M. L. (2016). Introduction to Qualitative Research Methods : a Guidebook and Resource (4th ed.). John Wiley \& Sons, Inc.

Wahono, S. B., \& Jabar, C. S. A. (2016). Keefektifan Supervisi Akademik Kepala Smk Negeri Kelompok Teknologi dan Rekayasa di Kabupaten Kebumen. Jurnal Akuntabilitas Manajemen Pendidikan, 4(2). https://doi.org/https://doi.org/10.21831/amp.v4i2.10808

Wahyudi, A., Narimo, S., \& Wafroturohmah, W. (2020). Kepemimpinan Pembelajaran Kepala Sekolah Dalam Meningkatkan Hasil Belajar Siswa. Jurnal VARIDIKA, 31(2), 4755.

Wardhana, R. A. N. (2016). Pengaruh Kepemimpinan Kepala Sekolah, Profesionalisme dan Pelatihan Guru Terhadap Implementasi Kurikulum 2013 Smkn Yogyakarta. Jurnal Akuntabilitas Manajemen https://doi.org/https://doi.org/10.21831/amp.v4i2.10812

Werdayanti, A. (2008). Pengaruh Kompetensi Guru Dalam Proses Belajar Mengajar di Kelas dan Fasilitas Guru Terhadap Motivasi Belajar Siswa. Dinamika Pendidikan, 3(1). https://doi.org/https://doi.org/10.15294/dp.v3i1.434

Yin, R. K. (2011). Qualitative Research from Start to Finish. A Division of Guildford Publications, Inc. 